\title{
Future of Container Shipping in Iranian Ports: Traffic and Connectivity Index Forecast
}

\author{
Roozbeh Panahi, Ali Ghasemi Koohi Kheili, and Amir Golpira \\ Civil and Environmental Engineering Department, Tarbiat Modares University, Tehran, Iran \\ Correspondence should be addressed to Roozbeh Panahi; rpanahi@modares.ac.ir
}

Received 11 June 2017; Revised 10 September 2017; Accepted 11 October 2017; Published 16 November 2017

Academic Editor: Andrea Monteriù

Copyright (C) 2017 Roozbeh Panahi et al. This is an open access article distributed under the Creative Commons Attribution License, which permits unrestricted use, distribution, and reproduction in any medium, provided the original work is properly cited.

\begin{abstract}
Rapid development of maritime container transport within the last two decades encouraged port authorities to focus on a more precise traffic forecast in order to cope with software and hardware requirements just in time. It has been the case for Iranian Ports and Maritime Organization (PMO) to map marine traffic until 2025. This has been performed in this paper based on three distinct scenarios, namely, "simplified continuous growth," "port best experience replication," and "regional best practice" for four main container ports of the country based on seventeen years recorded trade data. Such results should be used as input to assess smoothness of port functions in future. Besides, Liner Shipping Connectivity Index (LSCI) has been discussed to draw Iran's probable participation in the global container trade and shipping services within the next ten years.
\end{abstract}

\section{Introduction}

An estimation of future demand data, including import, export, transit, and transhipment, provides significant information while discussing port planning. When a port supply capacity is more than its market demand, port facilities and related investment lose their efficiency and here comes a lower internal rate of return. On the other hand, an excess of demand over supply causes an increase in cargo and ship traffic as well as waiting times; resulting in higher port total cost and a gradual reduction in port calls. Despite this frequent supply-demand challenge in the maritime industry, a decision supporting system is still inevitable. Decisionmaking requires a thorough understanding of future market demand as well as related ship traffic to handle it, in order to react carefully and quickly based on designed and assessed change plans on port supply side.

All in all, capturing demand-supply model needs a trial and error coupled procedure, including lots of parameters and assumptions. Considering such speculations, the procedure still would be very complex, especially when discussing a set of ports in a national scope rather than one port itself. On the other hand, by supposing that time-history data include reliable market understanding, the procedure could be simplified by decoupling those parts. In other words, one could extract demand and then look for its related marine traffic based on their previous correlations and designed scenarios. These two approaches have been frequently used overseas.

Generally, port demand prediction requires a comprehensive analysis including lots of assumptions. As a clear example, Hamburg port Consulting GmbH (HPC) and TarhNo-Andishan consulting engineers company (TNA) port (2003) proposed Iranian commercial ports master plan considering microeconomic and macroeconomic factors [1]. They mapped future of Iranian commercial ports demands according to three approaches designed by Strengths, Weaknesses, Opportunities, and Threats (SWOT) analysis. Medda and Carbonaro (2007) considered political, economic and technical factors in order to analyze past trends of container cargo traffic in the Mediterranean sea ports considering evolutions in their routes [2]. They concluded that a transparent understanding of the policy, economy, and technological frameworks as well as approaches that have been and continue to be the backbone for ongoing development of modern Mediterranean shipping activity allows one to outline strategies for future development of the basin.

In another research performed by Jugovic et al. (2011), they reviewed previous studies about demand prediction in Croatia ports to show large deviation from actual 
condition [3]. Goulielmos and Kaselimi (2011) forecasted container traffic of Piraeus port by using nonlinear radial basis functions based on 427 months of transhipment data between 1973 and 2008 [4]. Lopez et al. (2014) predicted volumes of Ro-Ro freight using Autoregressive Integrated Moving Average (ARIMA) regression and Artificial Neural Network (ANN) model in the port of Algeciras [5]. Royal HaskoningDHV (2014) forecasted the demand of port of Metro Vancouver in Canada until 2050 [6]. According to this study, factors such as North American container ports demand, macroeconomic trends in North America, and economic drivers affect the accuracy of prediction models [6]. Hong et al. (2017) used ANN to predict container flows among major ports of Asia considering Gross Domestic Products (GDP), interest rates, value of export and import trade, number of export and import containers and number of quay cranes [7]. The forecasting results indicate that the prediction errors are relatively small in most selected ports, and thus shipping companies can use the container flow prediction model to make decisions concerning operations. The results can be applied to the trend analysis of container ship flows among the major ports of Asia. Additionally, a community analysis of the container ships was conducted for the purpose of supply chain management.

Sazeh Pardazi Iran (SPI) consultant engineers have performed a study to forecast Iranian ports demands and supplies from 2016 to 2025 [9, 10]. It should be mentioned that the present study was performed as a part of "Update of Iranian Commercial Ports Master Plan" project conducted by Sazeh Pardazi Iran (SPI) company. Port service description of the study included eleven Iranian commercial ports as Shahid Rajaee, Imam Khomeini, Bushehr, Chabahar, Khorramshahr, Shahid Bahonar, Lengeh, and Abadan ports in the southern district of the country and Anzali, Amirabad, and Nowshahr in the northern districts of the country. SPI has performed the study by using Autoregressive Distributed Lag (ARDL) method $[9,10]$. Here, future ten years' demand of four main container ports, including Shahid Rajaee port, Imam Khomeini port, Chabahar port, and Bushehr port (Figure 1) with a total throughput of 30.94 million tons in 2016, as the main focus of this paper is summarized in Table 1. As shown in this table, Shahid Rajaee port has the largest share of container throughput among Iranian main container ports. The target ports in this study have $99 \%$ share of container throughput in the country.

HPC and TNA (2003) also forecasted traffic of Iranian commercial ports for ten years using an uncoupled procedure. They designed three scenarios, including constant development, unipolar system, and multipolar system to assign rational demand to each of the ports [1]. Poncela (2003) proposed the process of forecasting traffic in Spanish ports in several stages including interviews and exploitation, macroeconomic analysis, reports by sector, use of Delphi surveys, and trend analysis [11]. In other research, Hajbi (2011) tried to specify the relationship between port governance mode and its traffic in Morocco [12]. He also used linear regression to set a correlation between container shipping and GDP of the country [12]. Tsai and Huang (2016) forecasted development of Tuas Mega port in Singapore based on interviews and a

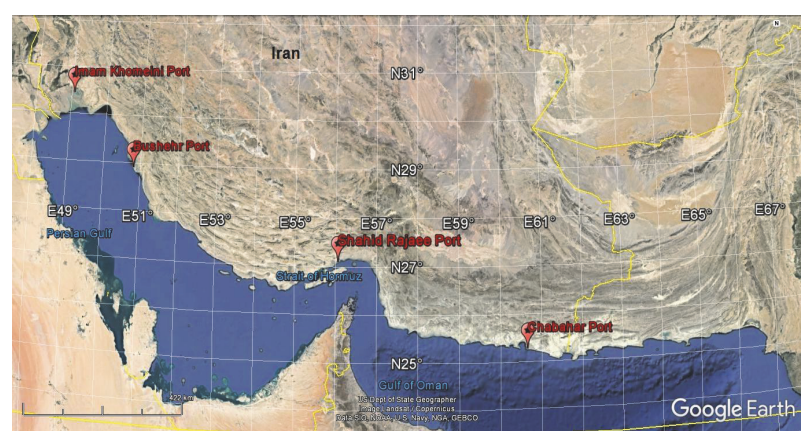

FIGURE 1: Location of main container Iranian ports [8].

single case study that provides necessary information in the container port operations, including factors that provide the impetus for the upgrades of the port facilities and technology [13].

Based on the literature, in spite of relatively widespread study performed regarding port demand forecasting; less attention has been paid on marine traffic forecasting of target ports while there is an inevitable linkage between them. On the other hands, determining port design ship has been researched overseas as it has been included in related rules and regulations $[14,15]$, but it is not well documented when discussing the fleet responsible for forecasted cargo handling while it is a very important step when either starting port planning $[15,16]$ or trying to recognize port bottlenecks.

To this end, the paper mainly aims at representing container shipping responsible for predicted demand. On this account, the paper is divided into three main sections. At first, methodology of the study and designed scenarios have been expressed in Section 2. Then, they have been applied with details on Shahid Rajaee port, as the most important container port of Iran, in Section 3. By repeating the procedure for other ports, outputs have been summarized for the other ones as well. Finally, LSCI has been introduced and forecasted for Iranian ports until 2025 in Section 4.

Here, it should be noted that such presented prediction has been used in the national project to plan ports software and hardware development by assessing their supply capacity as well as bottlenecks in response to the traffic, for example, lack of piers, cranes, and inland network. It is worth mentioning that ports' supply studies were also performed by SPI based on the service description of the main project with respect to presented port traffic [9]. The results showed that some of ports aspects, for example, number of container berths, number of gantry cranes, and depth of berths should be increased and developed in the future to meet market demands.

\section{Materials and Methods}

2.1. General Procedure. One requires reasonable scenarios in order to predict container ship traffic in ports. Here comes a preliminary important step to comprehensively survey international, regional, and national market based on (a) literature reviews, (b) interviews with national shippers, shipping 
TABLE 1: Forecasted demand of four Iranian main container ports until 2025 (1000 tons) [9].

\begin{tabular}{lccccccccc}
\hline Port name & 2017 & 2018 & 2019 & 2020 & 2021 & 2022 & 2023 & 2024 & 2025 \\
\hline Shahid Rajaee & 30,774 & 36,953 & 42,827 & 47,968 & 52,925 & 57,981 & 63,281 & 68,908 & 74,918 \\
Imam Khomeini & 2,019 & 2,381 & 2,718 & 3,042 & 3,375 & 3,735 & 4,129 & 4,565 & 5,048 \\
Bushehr & 1,341 & 1,438 & 1,625 & 1,775 & 1,936 & 2,110 & 2,295 & 2,495 & 2,709 \\
Chabahar & 758 & 924 & 1,089 & 1,920 & 4,086 & 4,252 & 4,418 & 5,251 & 5,419 \\
\hline Total & 34,892 & 41,696 & 48,259 & 54,705 & 62,322 & 68,078 & 74,123 & 81,219 & 88,094 \\
\hline
\end{tabular}

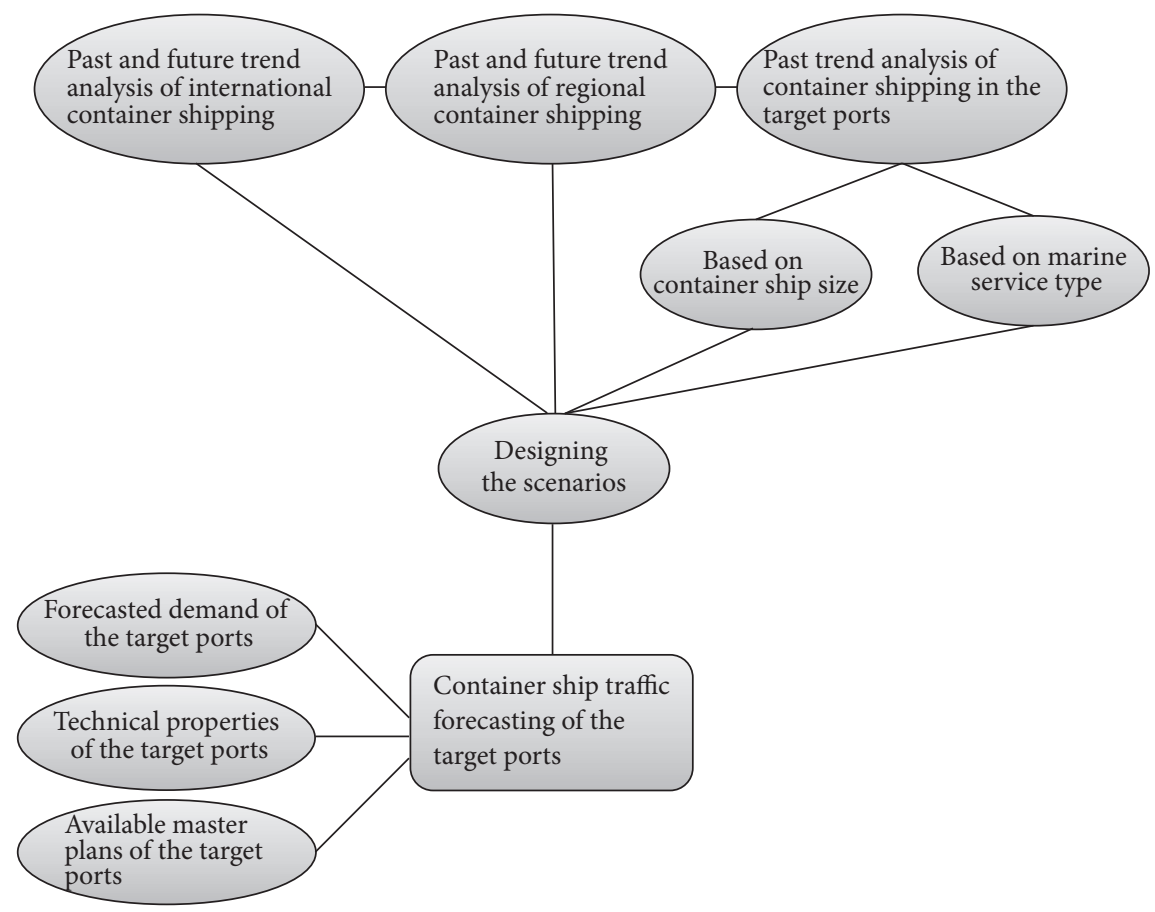

FIGURE 2: Methodology of traffic forecasting in target ports.

companies, and industrial decision makers $[6,9,10]$, and (c) assessment of experienced time-history of trade in target port (see Figure 2). After such investigations and drawing facts and figures, different scenarios were developed and then scored in a simple multicriteria analysis to extract three scenarios in order to cover a spectrum of probable events ahead of Iranian ports. So, at the first step, international maritime transport of container ships has been studied and the future outlook of the container shipping industry has been investigated based on well-known international documents generated by DNV [17], SEA EUROPE [18], and UNCTAD [19]. According to the aforementioned studies, world economic situation, container transport demand, container fleet age, and new orders in container ships are among the most important parameters to understand the future of the container shipping industry. Based on the DNV study on the shipping industry, container transport demands are influenced by ongoing changes in trade patterns, some of which can be regarded as emerging long-term trends, including slowdown in the growth of the mainline trades, Asia-North America, and Asia-Europe and an increase in the Europe-Middle East, Middle EastAsia, and South America-Africa-Asia trade routes. Mainline trades are growing at approximately $5 \%$ per annum whereas non-mainline trades are growing at an annual rate of $10 \%$ or more. The growth in Inter-Asia and Inter-China trade is even stronger [17]. SEA EUROPE forecasting shows that the new-building ships requirements will increase in the coming years, even at relatively low levels. However, the increase of transport needs and environmental considerations will influence the need for the replacement of the fleet and this will show up in the demand. Its forecast is based on macroeconomic forecasts, taking the economic development in the world and the global production, energy consumption, and the expectation for future energy mix into consideration [18].

Afterwards, the study has been focused on the regional maritime transport in the Persian Gulf and the Gulf of Oman. In this step, the main port specifications in the region, their port calls, and their future development plans have been analyzed. Study on the regional maritime transport has shown that Jebel Ali port, operated by DP World UAE Region, is the largest marine terminal in the Middle East and is ranked the 9th largest container port worldwide. It is a premier gateway for over 90 weekly services connecting more than 140 ports worldwide. Expansions currently underway at the port will bring total handling capacity to 22.1 million TEU by 
2018. Also, active container shipping companies in the region have been identified and their ship sizes investigated. It is worth mentioning that Jebel Ali port is the only port in the region that is equipped to receive the world's largest container vessel in the full load condition with an overall length of 399.2 meters, a moulded beam of 59.00 meters, and a maximum draft of 16.50 meters. The ship belongs to Maersk shipping line, as one of the largest shipping companies in the world which operates the carrier on its $2 \mathrm{M}$ Europe-Asia route.

In the next step, the past and present trends of container ship traffic in the target ports have been analyzed based on the size of container ships and their services in Shahid Rajaee port, Imam Khomeini port, Chabahar port, and Bushehr ports. The data used for the analysis in this research are given from PMO. The data include International Maritime Organization (IMO) number, ship name, type, Deadweight Tonnage (DWT), Gross Registered Tonnage (GRT), length overall, breadth moulded, full load draft, and the cargo volume carried by ships individually since 1999 until 2015. On this account, more than 102,000 records of container vessels which called Shahid Rajaee port, Imam Khomeini port, Chabahar port, and Bushehr port have been categorized into seven groups based on their DWT. Although twenty-foot equivalent unit (TEU) is a more common unit in the market rather than DWT, the recorded TEU data were incomplete. Therefore, container ships have been categorized based on their DWT (there are relations to convert DWT to TEU; the average loaded container weighs about 10-12 tons but, of course, this may vary, so the modern container vessels are dimensioned for 12-14 DWT per TEU [20]) in following categories:
(1) DWT $<10,000$ tons
(2) 10,000 tons $<$ DWT $<30,000$ tons
(3) 30,000 tons $<$ DWT $<60,000$ tons
(4) 60,000 tons $<$ DWT $<80,000$ tons
(5) 80,000 tons $<$ DWT $<120,000$ tons
(6) 120,000 tons $<$ DWT $<150,000$ tons
(7) DWT $>150,000$ tons.

Then, three probable predicting scenarios have been designed and applied on four target ports.

2.2. Scenarios. It should be noted that scenarios are not prediction of the future as such but rather stories of what the future might look like. According to the traffic forecasting strategy presented by PIANC [21], at the first stage, a wide range of scenarios were prepared and then, they refined and decreased into three probable scenarios during the forecast progress and interview with some shippers, shipping companies, and industrial decision makers of the country. Moreover, the potential future changes in vessel dimensions and technology, target ports, and other important ports in the region have been considered in scenario design and forecast progress.

Among three aforementioned scenarios, the first and second one are based on the analysis of past trend of container ships categories that called target ports. In the third scenario, changes in the global and regional container ships categories are taken into consideration. In the following paragraphs, these scenarios are explained.

(i) First scenario (simplified continuous growth): the concept of this scenario is based on the assumption that the future combination of marine traffic will be equal to mean of the five peak years of the port from 1999 to 2015 . In these peak years which might not be sequential, the port experiences the highest throughput. The parameters including the average share of each of container ship group in port container throughput, the average amount of cargo quantity of container ship per its own capacity, and the average capacity of each container ship group in five peak years are playing important roles in the traffic forecasting procedure as illustrated in Figure 3.

(ii) Second scenario (port best experience replication): the main idea of this scenario is based on the tendency of the share of container ships categories in port container throughput to grow or decrease in years ahead. Figure 4 illustrates three steps which are used in order to forecast the ship traffic of the target ports in the second scenario.

(iii) Third scenario (regional best practice): in this scenario, it is assumed that the average shares of each of the container ship categories in the container throughput of the port will emulate Jebel Ali port as the largest and a hub port in the region. Also, technical limitations of the target ports in comparison with Jebel Ali port have been considered, for example, waterway depth limitation with respect to OCDI (2009) and PIANC (2014) [14, 15]. Figure 5 illustrates the three steps for predicting container ship traffic of the target ports.

\section{Container Ship Traffic in the Target Ports}

3.1. Results of Traffic Forecasting for the Shahid Rajaee Port. In this section, three aforementioned procedures are explained in detail and the results are explained. The whole package is performed again for other target ports and the results are presented subsequently.

3.1.1. First Scenario. In Figure 6, the shares of each of the container ship categories in the container throughput and the total container throughput of Shahid Rajaee port are shown. According to this graph, the port experienced its maximum throughput from 2008 to 2012. Hence, the average share of each category of container ships is calculated among these five peak years. In the first scenario, it is assumed that the share of each container ship category in the container throughput will be constant until 2025. For instance, 34\% of container throughput of the Shahid Rajaee port was historically transported by 30,000 to 60,000 DWT container ships from 2008 to 2012, and it is assumed that the category will keep its share in container throughput until 2025. Also, 


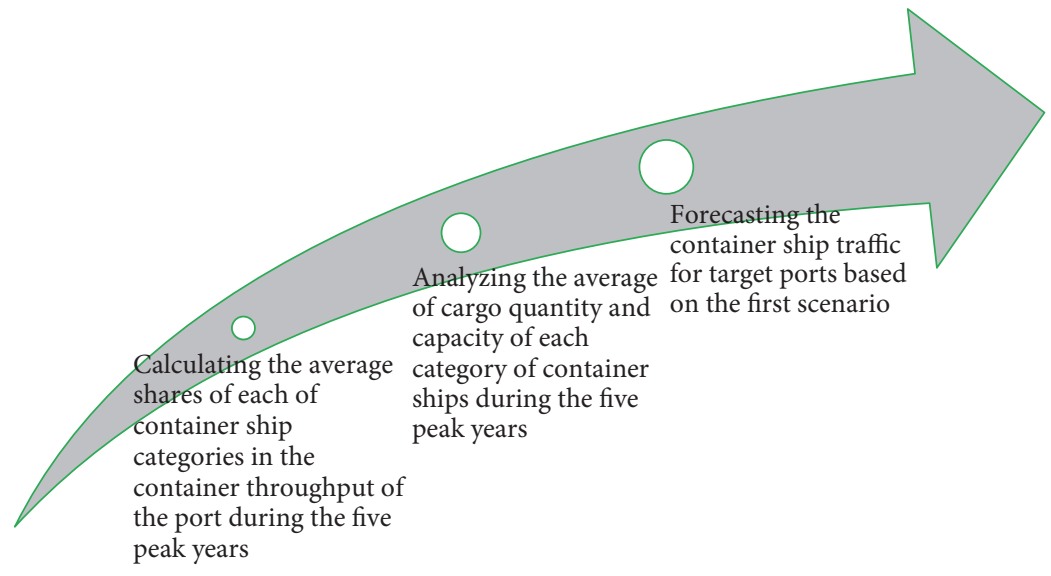

FIGURE 3: The procedure of forecasting container ship traffic in the first scenario.

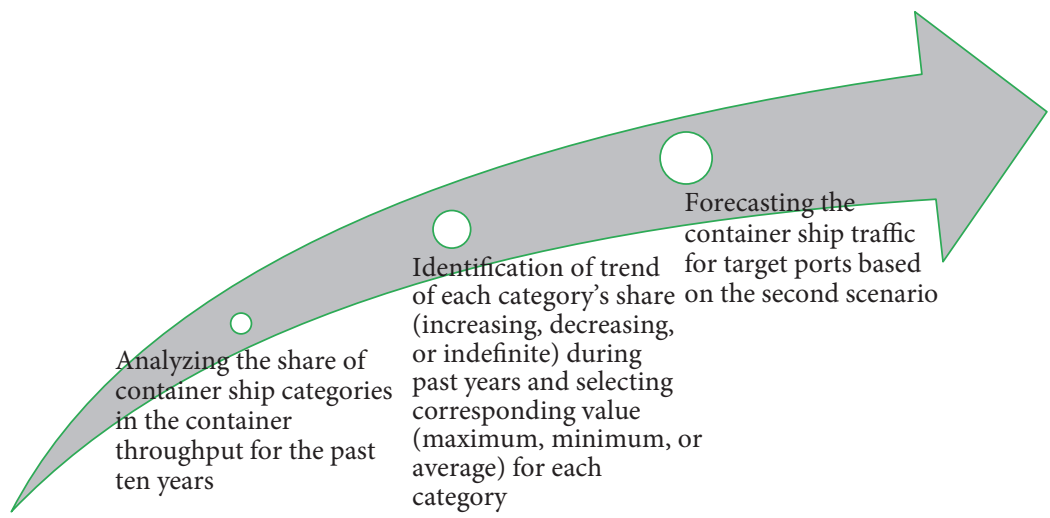

FIGURE 4: The procedure of forecasting container ship traffic in the second scenario.

the average cargo quantity and the average capacity for each type of container ships are represented in Figure 7. In order to calculate the average cargo quantity and capacity of each container ship category in future, those are also averaged over the five peak years and the results are applied for the future traffic.

Final results based on the first scenario are presented in Table 2. According to this table, the number of container ships annually calling Shahid Rajaee port will increase from 1382 in 2016 into 3020 in 2025. Although the container ships with 10,000 to 30,000 DWT will constitute the main part the port traffic, 30,000 to 60,000 DWT category will be responsible for the highest share of the port.

3.1.2. Second Scenario. In the second scenario, the trend of each container ship category share in container throughput is the main issue. In order to consider the trend, for those categories of container ships with a decreasing trend during the past 10 years, the minimum share that has been observed from 2006 to 2015 is chosen as their share in the future. For instance, the category of 10,000 to 30,000 DWT has a decreasing trend from 2006 to 2015, and its minimum observed share is $22.1 \%$. On the other hand, if the trend is in the increasing way, its maximum share observed during 2006 to 2015 will be chosen as the share of this group in the future. For those categories in which the trend has no clear pattern during the period, its average share is chosen as their share in years ahead. The share of each container ship category during the recent years has a significant role in the traffic prediction of the target ports. For example, according to Figure 8, it is clear that 10,000 to 30,000 DWT container ship category had a large share at the beginning, but in recent years their share has been gradually decreased. Somehow, the second scenario considers such variations in prediction.

Final results of traffic forecasting of the container ships in the Shahid Rajaee port based on the second scenario are presented in Table 3.

3.1.3. Third Scenario. The third scenario is based on the assumption that the container ships calling the target ports and their share in port throughput will be optimistically similar to Jebel Ali port as the best practice. In the first step, the share of each container ship category is extracted for Jebel Ali port by using AIS (Automatic Identification System) data. As shown in Figure 9, container ships with the capacity of more than 80,000 DWT have the largest share (59\%) in this port during 2014 and 2015. Consequently, in order to match the share of each group in the Shahid Rajaee port 


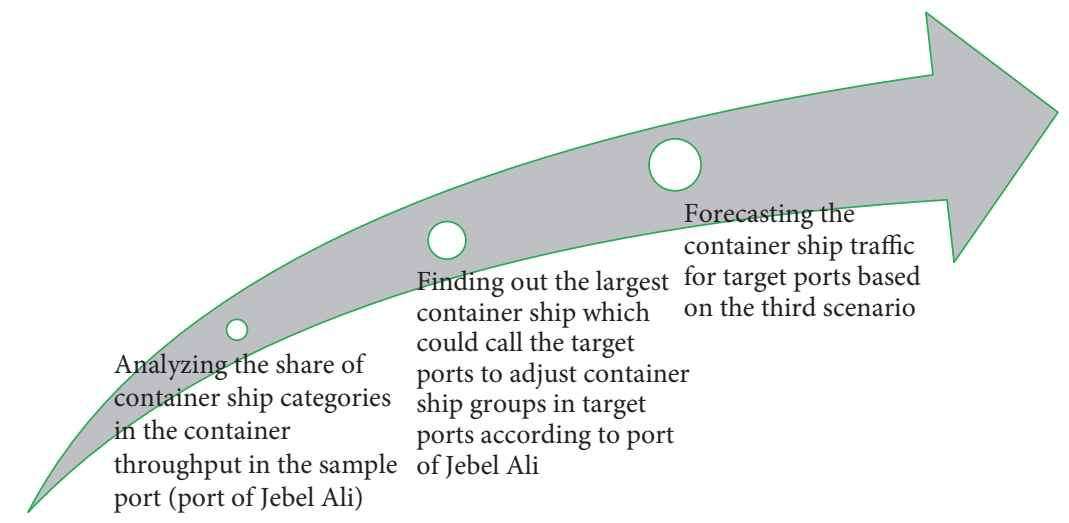

FIGURE 5: The procedure of forecasting container ship traffic in the third scenario.

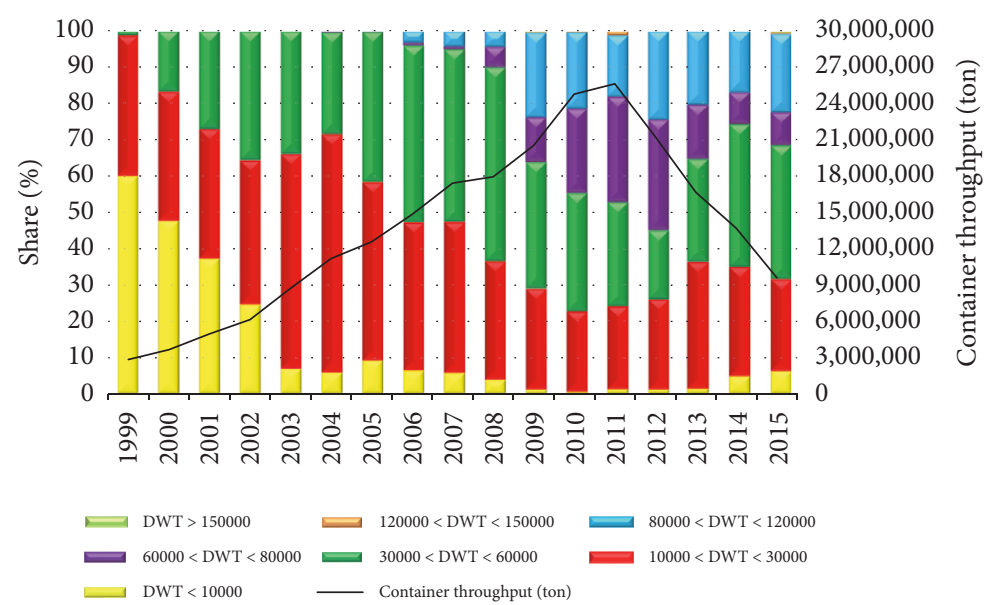

FIGURE 6: Share of container ships in cargo displacement during 1999 to 2015 and container throughput in the Shahid Rajaee port. Black line shows container throughput for each of the years. It can be seen that peak years of container throughput are 2008 to 2012.

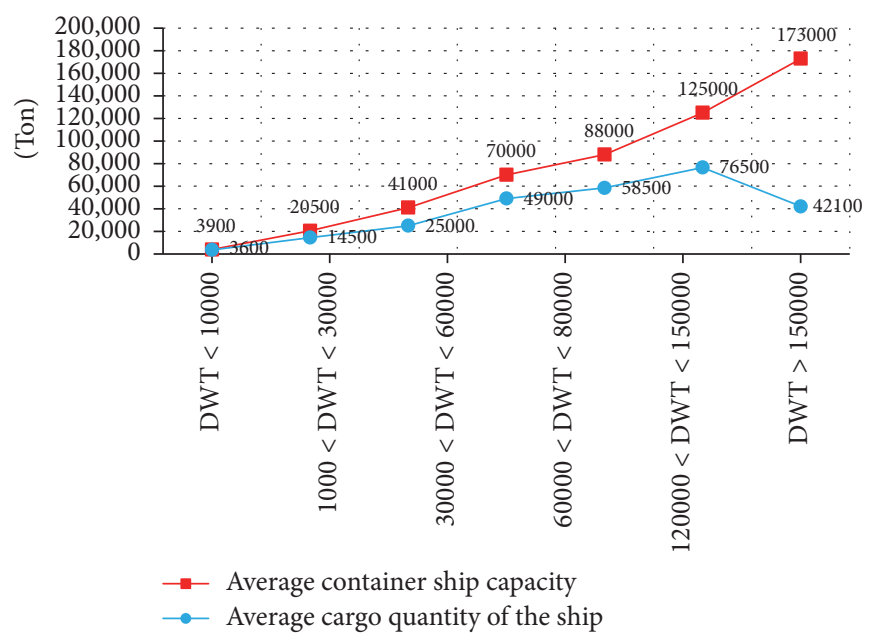

FIGURE 7: Average cargo quantity and capacity of the container ships of each group during the five peak years (2008, 2009, 2010, 2011, and 2012) in the Shahid Rajaee port. 
TABLE 2: Number of container ships and their carried cargo (ton) in port container throughput (predicted from 2017 to 2025) based on the first scenario.

\begin{tabular}{|c|c|c|c|c|c|c|c|c|c|}
\hline First scenario & Year & $\begin{array}{c}\text { DWT }< \\
10,000\end{array}$ & $\begin{array}{c}10,000< \\
\mathrm{DWT}< \\
30,000\end{array}$ & $\begin{array}{c}30,000< \\
\mathrm{DWT}< \\
60,000\end{array}$ & $\begin{array}{c}60,000< \\
\text { DWT }< \\
80,000\end{array}$ & $\begin{array}{c}80,000< \\
\mathrm{DWT}< \\
120,000 \\
\end{array}$ & $\begin{array}{c}120,000< \\
\text { DWT }< \\
150,000 \\
\end{array}$ & $\begin{array}{l}\text { DWT > } \\
150,000\end{array}$ & Total \\
\hline \multirow{9}{*}{$\begin{array}{l}\text { Number of } \\
\text { container ships } \\
\text { calling Shahid } \\
\text { Rajaee port }\end{array}$} & 2017 & 138 & 593 & 423 & 128 & 97 & 2 & 1 & 1,382 \\
\hline & 2018 & 166 & 712 & 508 & 153 & 117 & 2 & 1 & 1,659 \\
\hline & 2019 & 192 & 824 & 589 & 177 & 135 & 2 & 1 & 1,920 \\
\hline & 2020 & 214 & 924 & 660 & 199 & 151 & 3 & 1 & 2,152 \\
\hline & 2021 & 236 & 1,007 & 693 & 216 & 162 & 3 & 1 & 2,318 \\
\hline & 2022 & 260 & 1,089 & 725 & 223 & 172 & 3 & 1 & 2,483 \\
\hline & 2023 & 283 & 1,175 & 757 & 251 & 183 & 3 & 1 & 2,653 \\
\hline & 2024 & 308 & 1,267 & 789 & 270 & 193 & 3 & 1 & 2,831 \\
\hline & 2025 & 334 & 1,365 & 824 & 289 & 204 & 3 & 1 & 3,020 \\
\hline \multirow{9}{*}{$\begin{array}{l}\text { Carried cargo of } \\
\text { container ships in } \\
\text { port's throughput } \\
\text { (ton) }\end{array}$} & 2017 & 469,800 & $8,048,700$ & $10,405,800$ & $6,272,000$ & $5,548,400$ & 158,400 & 81,000 & $30,984,100$ \\
\hline & 2018 & 565,650 & $9,664,050$ & $12,496,800$ & $7,497,000$ & $6,692,400$ & 158,400 & 81,000 & $37,155,300$ \\
\hline & 2019 & 652,050 & $11,184,150$ & $14,489,400$ & $8,673,000$ & $7,722,000$ & 158,400 & 81,000 & $42,960,000$ \\
\hline & 2020 & 727,900 & $12,541,800$ & $16,236,000$ & $9,751,000$ & $8,637,200$ & 237,600 & 81,000 & $48,212,500$ \\
\hline & 2021 & 803,750 & $13,846,150$ & $17,900,190$ & $10,735,200$ & $9,551,520$ & 245,520 & 87,480 & $53,169,710$ \\
\hline & 2022 & 884,450 & $15,149,850$ & $19,618,500$ & $11,743,200$ & $10,443,800$ & 253,440 & 93,960 & $58,186,540$ \\
\hline & 2023 & 960,150 & $16,526,550$ & $21,415,530$ & $12,826,100$ & $11,433,840$ & 261,360 & 100,440 & $63,523,970$ \\
\hline & 2024 & $1,046,000$ & $18,004,500$ & $23,291,280$ & $13,986,000$ & $13,398,320$ & 269,280 & 106,920 & $69,102,300$ \\
\hline & 2025 & $1,135,450$ & $19,580,250$ & $25,338,000$ & $15,172,500$ & $13,464,000$ & 277,200 & 113,400 & $75,080,800$ \\
\hline
\end{tabular}

TABLE 3: Number of container ships and their carried cargo (ton) in port container throughput (predicted from 2017 to 2025) based on the second scenario.

\begin{tabular}{|c|c|c|c|c|c|c|c|c|c|}
\hline Second scenario & Year & $\begin{array}{c}\mathrm{DWT}< \\
10,000\end{array}$ & $\begin{array}{c}10,000< \\
\text { DWT }< \\
30,000\end{array}$ & $\begin{array}{c}30,000< \\
\mathrm{DWT}< \\
60,000\end{array}$ & $\begin{array}{c}60,000< \\
\text { DWT }< \\
80,000\end{array}$ & $\begin{array}{c}80,000< \\
\mathrm{DWT}< \\
120,000\end{array}$ & $\begin{array}{c}120,000< \\
\text { DWT }< \\
150,000\end{array}$ & $\begin{array}{l}\mathrm{DWT}> \\
150,000\end{array}$ & Total \\
\hline \multirow{9}{*}{$\begin{array}{l}\text { Number of } \\
\text { container ships } \\
\text { calling Shahid } \\
\text { Rajaee port }\end{array}$} & 2017 & 171 & 492 & 394 & 154 & 105 & 4 & 2 & 1,322 \\
\hline & 2018 & 205 & 591 & 473 & 185 & 126 & 5 & 2 & 1,587 \\
\hline & 2019 & 238 & 685 & 548 & 214 & 146 & 6 & 2 & 1,839 \\
\hline & 2020 & 266 & 767 & 614 & 240 & 164 & 6 & 2 & 2,059 \\
\hline & 2021 & 293 & 835 & 645 & 261 & 175 & 7 & 2 & 2,218 \\
\hline & 2022 & 322 & 905 & 674 & 282 & 186 & 7 & 2 & 2,378 \\
\hline & 2023 & 351 & 977 & 704 & 303 & 198 & 7 & 2 & 2,542 \\
\hline & 2024 & 382 & 1,054 & 734 & 326 & 209 & 8 & 2 & 2,715 \\
\hline & 2025 & 415 & 1,135 & 766 & 349 & 222 & 8 & 2 & 2,897 \\
\hline \multirow{9}{*}{$\begin{array}{l}\text { Carried cargo of } \\
\text { container ships in } \\
\text { port's throughput } \\
\text { (ton) }\end{array}$} & 2017 & 545,850 & $6,668,250$ & $9,692,400$ & $7,546,000$ & $6,006,000$ & 316,800 & 162,000 & $30,937,300$ \\
\hline & 2018 & 654,300 & $8,010,900$ & $11,635,800$ & $9,065,000$ & $7,027,200$ & 396,000 & 162,000 & $36,951,200$ \\
\hline & 2019 & 756,900 & $9,284,400$ & $13,480,800$ & $10,486,000$ & $8,351,200$ & 475,200 & 162,000 & $42,996,500$ \\
\hline & 2020 & 847,600 & $10,395,450$ & $15,104,400$ & $11,760,000$ & $9,380,800$ & 475,200 & 162,000 & $48,125,450$ \\
\hline & 2021 & 934,700 & $11,614,350$ & $17,453,700$ & $13,154,400$ & $10,626,000$ & 591,360 & 187,920 & $54,562,430$ \\
\hline & 2022 & $1,025,950$ & $12,562,350$ & $18,238,440$ & $14,212,800$ & $11,293,920$ & 591,360 & 187,920 & $58,112,740$ \\
\hline & 2023 & $1,117,200$ & $13,703,250$ & $19,916,160$ & $15,483,300$ & $12,371,040$ & 609,840 & 200,880 & $63,401,670$ \\
\hline & 2024 & $1,215,650$ & $14,927,850$ & $21,667,680$ & $16,886,800$ & $13,426,160$ & 718,080 & 213,840 & $69,056,060$ \\
\hline & 2025 & $1,323,550$ & $16,219,650$ & $23,554,500$ & $18,322,500$ & $14,652,000$ & 739,200 & 226,800 & $75,038,200$ \\
\hline
\end{tabular}




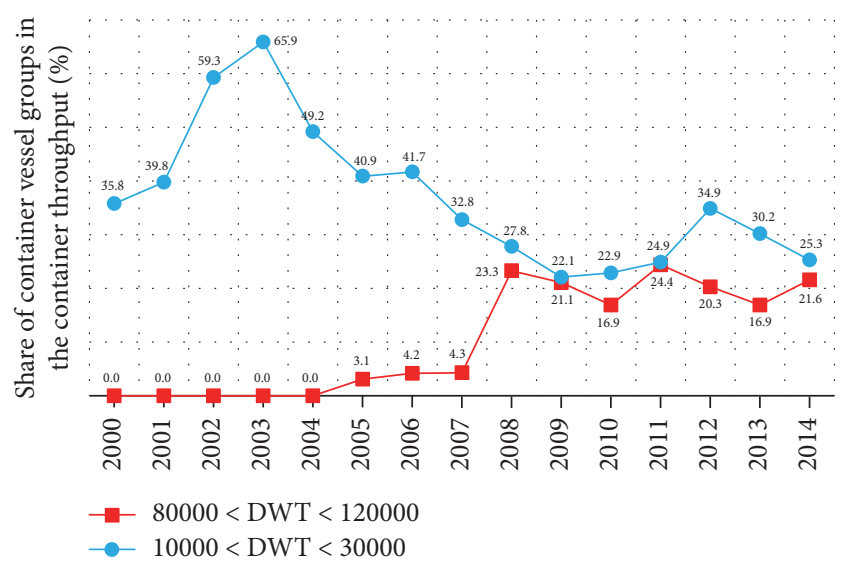

Figure 8: Share of 80,000 to 120,000 DWT and 10,000 to 30,000 DWT container ships in the container throughput during 2000 to 2015 in the Shahid Rajaee port.

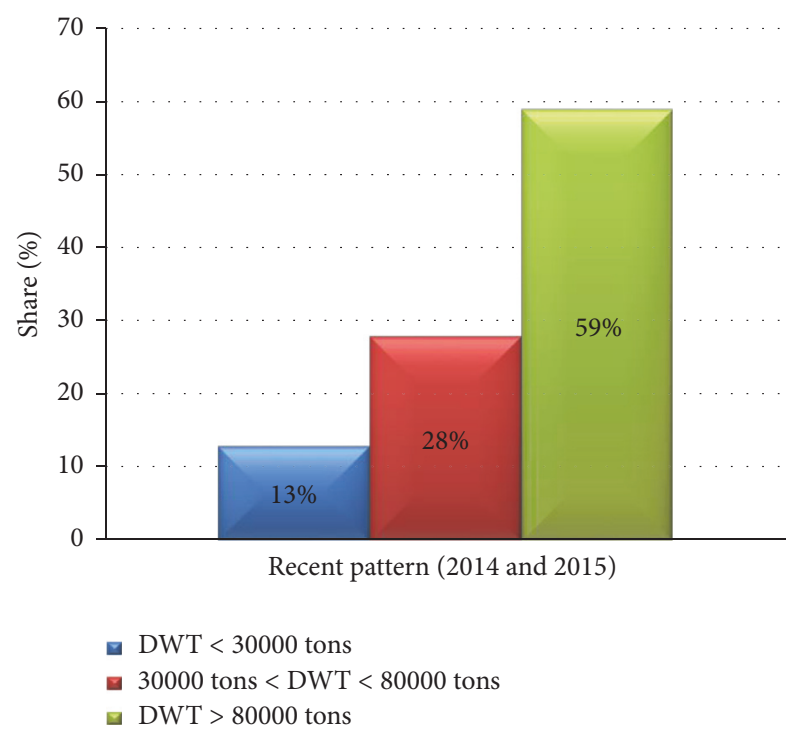

FIGURE 9: Share of each group of container ship of the container throughput in the port of Jebel Ali during 2014 and 2015.

and port of Jebel Ali, it is necessary for Shahid Rajaee port to increase the share of container ships with the capacity of more than 80,000 DWT in container throughput and reduce the share of container vessels with the capacity of less than 30,000 DWT in the following years. It is worth mentioning that the port of Jebel Ali is capable of servicing container ships with 240,000 DWT. However, the container ships that have a capacity of more than 200,000 DWT could not call Shahid Rajaee port due to the limitations such as the port entrance and the draft of the berth. Therefore, the share of more than 200,000 DWT container ships in Jebel Ali port will be assigned to more than 150,000 DWT container ships in our proposed categories. Table 4 shows the technical specifications of the design ships of port of Jebel Ali and Shahid Rajaee port.

Final results of traffic forecasting of the container vessels in the Shahid Rajaee port based on the third scenario are
TABLE 4: Technical specifications of the largest container ship (design vessel) that entered port of Jebel Ali and Shahid Rajaee port.

\begin{tabular}{lcccc}
\hline Port & Capacity & $\begin{array}{c}\text { Length } \\
(\mathrm{m})\end{array}$ & $\begin{array}{c}\text { Width } \\
(\mathrm{m})\end{array}$ & $\begin{array}{c}\text { Draught } \\
(\mathrm{m})\end{array}$ \\
\hline Jebel Ali & $\begin{array}{l}240,000 \mathrm{DWT} \\
(200,000 \mathrm{TEU})\end{array}$ & 440 & 60 & 18 \\
Shahid Rajaee & $\begin{array}{l}200,000 \mathrm{DWT} \\
(180,000 \mathrm{TEU})\end{array}$ & 390 & 59 & 16.5 \\
\hline
\end{tabular}

presented in Table 5. Obviously, 10,000 to 30,000 DWT container ships still will be responsible for the largest part of traffic, while the carried cargo of more than 80,000 DWT container ships in container throughput increases drastically. This increase was expectable because of the essence of this scenario as emulating a hub port like Jebel Ali port.

3.2. Results of Forecasting Container Ship Traffic in the Target Ports. According to mentioned procedure of forecasting container ships traffic of Shahid Rajaee port, and after applying the procedure on other target ports, the results of traffic forecasting are presented in Table 6 for the target ports.

\section{LSCI Forecasting}

4.1. Introduction to LSCI. A country's participation in global seaborne trade as well as frequent and reliable shipping services are important factors in determining nations' competitiveness of container transport [22]. In 2004, the United Nations Conference on Trade and Development (UNCTAD) developed a specific parameter in order to qualify nation's containerized liner trade which is known as Liner Shipping Connectivity Index or LSCI [23]. All countries with a high LSCI benefit from regular and frequent shipping services in their ports that place them at the center of international seaborne container trade. The others with a lower index are on the periphery of such activity. Hence, LSCI obviously measures connectivity of a country to international container trade and maritime transport networks [23].

LSCI focuses on ports with container terminals and consists of five variables, each one responsible for one aspect of container transport network connectivity [22, 23]. Figure 10 illustrates these five components represented by $\mathrm{C} 1$ to $\mathrm{C} 5$ in the present study. Also, the method of calculating LSCI is presented in Figure 11.

4.2. LSCI Analysis for Iran. Figure 12 shows the LSCI for Iranian ports from 2004 to 2016 according to data given by UNCTAD. As presented in this graph, the index has a continuous increase during 2004 to 2011. However, in the next three years, a severe decrease is observed due to international sanctions against Iranian shipping lines and other international shipping lines which have called Iranian ports. By lifting the sanctions, LSCI has started to mount again in the recent two years.

In order to verify the LSCI value presented by UNCTAD, it is calculated for Iranian ports based on the data of port calls given by the PMO of Iran and compared with the value 
TABLE 5: Number of container ships and their carried cargo (ton) in port container throughput (predicted from 2017 to 2025) based on the third scenario.

\begin{tabular}{|c|c|c|c|c|c|c|c|c|c|}
\hline Third scenario & Year & $\begin{array}{c}\mathrm{DWT}< \\
10,000\end{array}$ & $\begin{array}{c}10,000< \\
\text { DWT }< \\
30,000\end{array}$ & $\begin{array}{c}30,000< \\
\mathrm{DWT}< \\
60,000\end{array}$ & $\begin{array}{c}60,000< \\
\text { DWT }< \\
80,000\end{array}$ & $\begin{array}{c}80,000< \\
\mathrm{DWT}< \\
120,000\end{array}$ & $\begin{array}{c}120,000< \\
\mathrm{DWT}< \\
150,000\end{array}$ & $\begin{array}{l}\text { DWT > } \\
150,000\end{array}$ & Total \\
\hline \multirow{9}{*}{$\begin{array}{l}\text { Number of } \\
\text { container ships } \\
\text { calling Shahid } \\
\text { Rajaee port }\end{array}$} & 2017 & 139 & 219 & 213 & 126 & 92 & 51 & 80 & 920 \\
\hline & 2018 & 167 & 262 & 256 & 151 & 110 & 61 & 96 & 1,103 \\
\hline & 2019 & 193 & 304 & 296 & 175 & 128 & 71 & 112 & 1,279 \\
\hline & 2020 & 216 & 340 & 332 & 196 & 143 & 79 & 125 & 1,431 \\
\hline & 2021 & 239 & 365 & 349 & 213 & 153 & 85 & 128 & 1,532 \\
\hline & 2022 & 262 & 389 & 365 & 231 & 163 & 90 & 130 & 1,630 \\
\hline & 2023 & 285 & 415 & 381 & 248 & 173 & 95 & 133 & 1,730 \\
\hline & 2024 & 310 & 442 & 397 & 267 & 183 & 100 & 136 & 1,835 \\
\hline & 2025 & 338 & 470 & 415 & 286 & 193 & 106 & 139 & 1,947 \\
\hline \multirow{9}{*}{$\begin{array}{l}\text { Carried cargo of } \\
\text { container ships in } \\
\text { port's throughput } \\
\text { (ton) }\end{array}$} & 2017 & 619,650 & $3,099,750$ & $5,239,800$ & $6,174,000$ & $5,262,400$ & $4,039,200$ & $6,480,000$ & $30,914,800$ \\
\hline & 2018 & 745,200 & $3,707,700$ & $6,297,600$ & $7,399,000$ & $6,292,000$ & $4,831,200$ & $7,776,000$ & $37,048,700$ \\
\hline & 2019 & 861,300 & $4,302,600$ & $7,281,600$ & $8,575,000$ & $7,321,600$ & $5,623,200$ & $9,072,000$ & $43,037,300$ \\
\hline & 2020 & 962,100 & $4,811,400$ & $8,167,200$ & $9,604,000$ & $8,179,600$ & $6,256,800$ & $10,125,000$ & $48,106,100$ \\
\hline & 2021 & $1,065,150$ & $5,308,650$ & $9,014,670$ & $10,586,100$ & $9,020,880$ & $6,956,400$ & $11,197,440$ & $53,149,290$ \\
\hline & 2022 & $1,168,200$ & $5,804,400$ & $9,876,900$ & $11,642,400$ & $9,897,360$ & $7,603,200$ & $12,214,800$ & $58,207,260$ \\
\hline & 2023 & $1,271,250$ & $6,343,950$ & $10,778,490$ & $12,672,800$ & $10,809,040$ & $8,276,400$ & $13,358,520$ & $63,510,450$ \\
\hline & 2024 & $1,381,500$ & $6,906,600$ & $11,719,440$ & $13,830,600$ & $11,755,920$ & $8,976,000$ & $14,541,120$ & $69,111,180$ \\
\hline & 2025 & $1,507,050$ & $7,501,500$ & $12,761,250$ & $15,015,000$ & $12,738,000$ & $9,794,400$ & $15,762,600$ & $75,079,800$ \\
\hline
\end{tabular}

represented by UNCTAD in Table 7. As mentioned before, Iran's values for each component ( $\mathrm{C} 1$ to $\mathrm{C} 5)$, respectively, are divided into the maximum value of each component in 2004 which belongs to China. LSCI components of Iran based on UNCATD data were separately available just for year 2011 and in other years final value of LSCI was available. So the LSCI value is calculated for 2011. According to Table 7, the calculated LSCI based on PMO data has some 30\% difference with UNCTAD.

In Figure 13, the past trend of $\mathrm{C} 1$ to $\mathrm{C} 5$ is presented for Iranian ports. A similar trend is obvious for all variables as there is a gradual growth from 2004 to 2011 and then an abrupt decrease occurs due to sanctions against Iranian shipping lines and ports. However, a gradual growth has occurred after sanction nullification.

One of the important factors in analyzing $\mathrm{C} 1$ to $\mathrm{C} 5$ variables is the ratio of $\mathrm{C} 4$ to $\mathrm{C} 3$, which means the proportion of the number of liner services to the number of companies that deploy container ships on services from and to a country's ports. According to UNCTAD recommendation, this ratio varies from one country to another. However, the average of this ratio is approximately equal to 4 and for China, it is equal to 6 [24]. Analysis of the recorded data of port calls in Iranian ports has shown that this ratio is about 2.5 for Iranian ports.

Based on the explanations, Figure 14 shows LSCI prediction for Iranian ports from 2017 to 2025 based on container ship traffic presented in former sections. Actually, components of LSCI are calculated based on three proposed scenarios. According to Figure 14, the LSCI values for Iranian ports will be greater based on the third scenario. Also, the growth rate of LSCI for Iranian ports is higher for third scenario. The growth rate of LSCI from 2017 to 2021 is $4 \%$, $6 \%$, and $11 \%$ and from 2022 to 2025 is $3 \%, 4 \%$, and $4 \%$ in the first, second, and third scenario, respectively.

As shown in the graph, the LSCI that is calculated based on first and second scenarios has increased three times in 2025 in comparison with its value in 2016. Generally first and second scenarios have similar results and LSCIs in these two scenarios have a less than $5 \%$ difference. Although the values of $\mathrm{Cl}$ to $\mathrm{C} 4$ in second scenario are more than the values in the first scenario, C5 is equal in both of them. It seems that this consistence is the main reason of little difference of LSCI in first and second scenario. As expected according to the third scenario, LSCI has optimistically the largest growth (5 times in comparison to 2016). This result was foreseeable due to essence of third scenario that assumes Iranian ports emulate a hub port like Jebel Ali port.

\section{Conclusion}

This paper has proposed a method to predict Iranian main container ports, including Shahid Rajaee port, Imam Khomeini port, Chabahar port, and Bushehr port, also applicable to other container ports. In order to design this method, three scenarios have been devised based on three concepts: simplified continuous growth, port best experience replication, and regional best practice of target ports. More than 102,000 records of container ships which called target ports were categorized into seven categories based on their DWT. The numbers of container ships and their share in container 


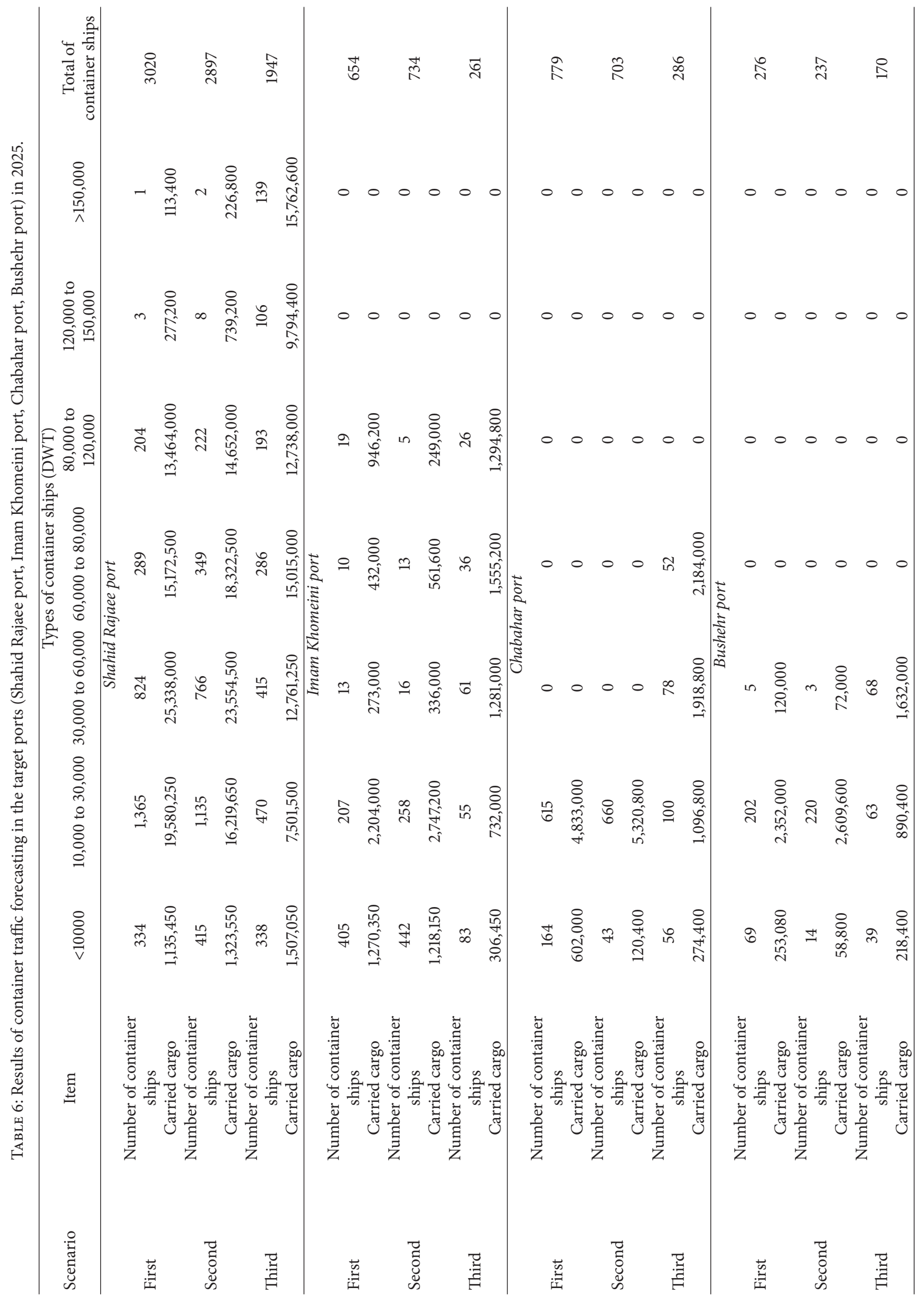




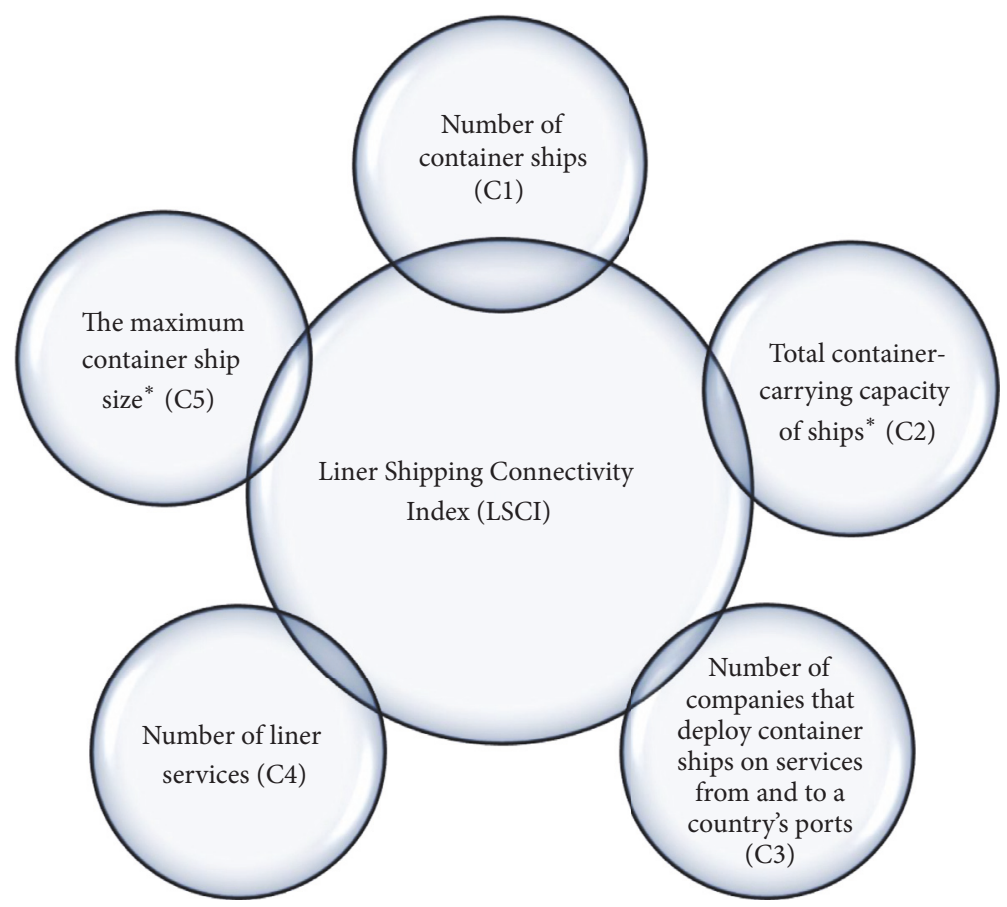

FIgURE 10: Components of LSCI. *: unit is TEU.

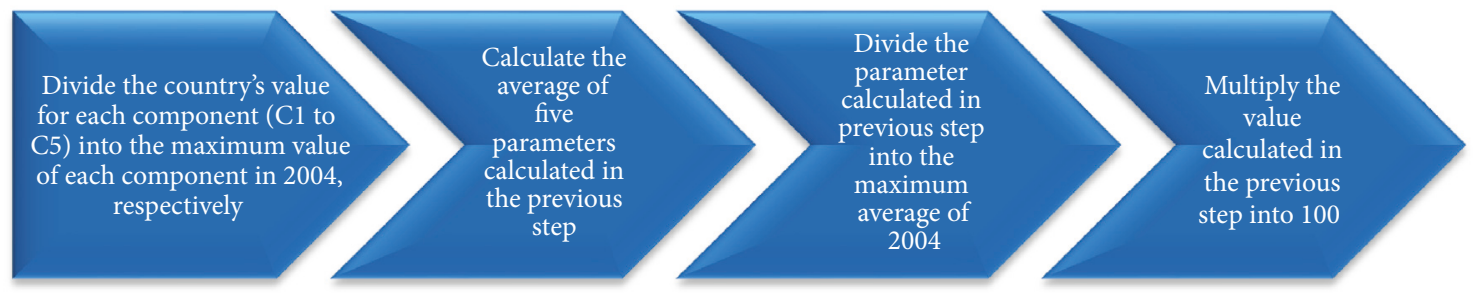

FIGURE 11: Process of calculating LSCI for a country.

TABLE 7: Iran's LSCI in terms of its components for 2011 based on UNCTAD and PMO data (the components of China in 2004 is presented as a source of calculation for Iran's LSCI).

\begin{tabular}{lccc}
\hline Year source & $\begin{array}{c}2004 \text { UNCTAD } \\
\text { Country }\end{array}$ & $\begin{array}{c}\text { 2011 UNCTAD } \\
\text { China }\end{array}$ & 2011 PMO Iran \\
\hline C1 & 1228 & 88 & 184 \\
C2 (ton) & $3,928,913$ & 355,357 & 728,580 \\
C3 & 96 & 20 & 32 \\
C4 & 863 & 50 & 89 \\
C5 (TEU) & 8,238 & 8,600 & 10,930 \\
\hline LSCI & 100 & 29.95 & 40.77 \\
\hline
\end{tabular}

throughput of target ports during 2017 to 2025 for each category have been forecasted by using of designed scenarios. According to the first and second scenario, the 30,000 to 60,000 DWT container ships will have the largest share in port's throughput and 10,000 to 30,000 DWT container ships will constitute the major part of traffic in Shahid Rajaee port in the future. In three other ports, the 10,000 to $30,000 \mathrm{DWT}$

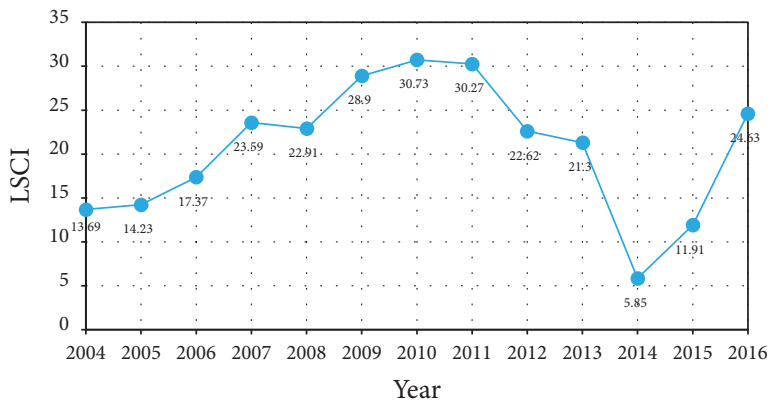

FIGURE 12: LSCI trend for Iranian ports from 2004 to 2016 (based on UNCTAD data).

container ships will have the largest share and the main part of traffic according to first and second scenario. The concept of the third scenario leads to an increase in the share of container ships with larger capacities and it is predicted that the container ships larger than 150,000 DWT will have the largest share in the port's container throughput of the Shahid Rajaee port. In other target ports, the category with largest 


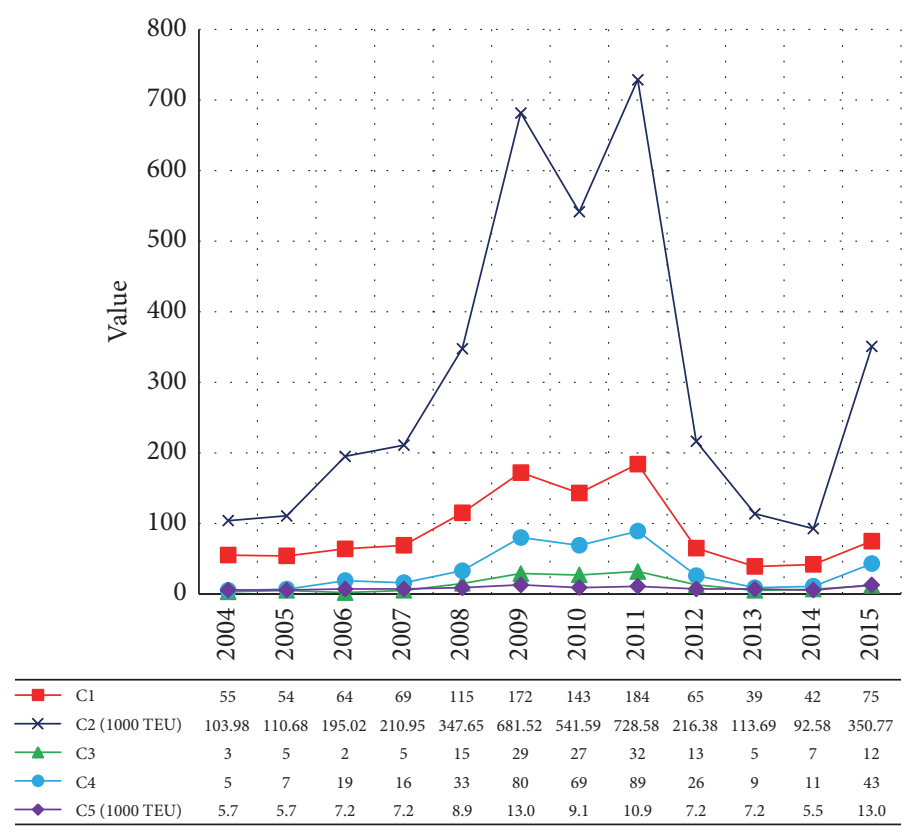

FIgURE 13: Past trends of LSCI's components based on PMO data.

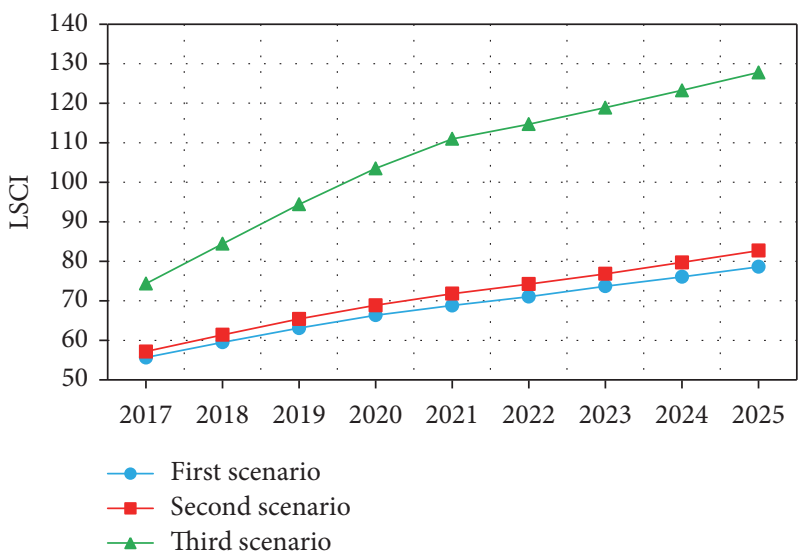

FIGURE 14: Trend of Iran's LSCI during 2017 to 2025.

DWT has the largest share in ports throughput. Additionally, although in the first and second scenarios some categories of container ships have a marginal share in total container throughput of the ports, obviously throughput of ports has distributed more equally based on the third scenario.

Applying three scenarios on LSCI for Iranian ports shows that the first and second scenarios are very similar to each other and the LSCI will increase from about 55 to 70 with an almost consistent trend from 2017 to 2025 for both scenarios. On the other hand, the LSCI for Iranian ports increases with a slightly higher but consistent slope to about 130 in 2025 for the optimistic third scenario. This value is 5 times more than the current state.

Economic and political factors affect port connectivity to international container trade and maritime transport networks; so that Iranian ports encountered a severe decrease in their connectivity to international shipping lines and port calls due to international sanctions against the country in 2012, 2013, and 2014. Although the method employed in this paper does not consider political and economic factors directly, analysis of past trends of ports and also comparing them with a well-known hub port in the region (Jebel Ali port) can compensate political and economic factors such as legislation of ports in the country.

All in all, reviewing literature and similar studies in the country and analyzing the results of the present study show that the scenarios which are based on the analysis of past trends is more likely to happen in the future. Taking into consideration restrictions and limitations to develop some aspects of ports, such as depth of ports' basin and berths and construction of new berths with higher capacity, in comparison with global and regional competitors, the third scenario seems unlikely to happen in the country.

\section{Conflicts of Interest}

The authors declare that they have no conflicts of interest.

\section{Acknowledgments}

This work was conducted under a research contract with the Iranian Ports and Maritime Organization (PMO) that is entitled "Review of the Iranian Commercial Ports Master Plan." The authors would like to use this opportunity to express their gratitude to everyone who supported them throughout this research specially staff of PMO's Strategic Studies and Researches Center for their very valuable comments on this research. Authors also would like to highly appreciate Sazeh Pardazi Iran (SPI) company for their full support of this research. 


\section{References}

[1] “TARH-E Now Andishan Consulting Eng.Co," http://www .tna-co.ir/projects/ProjectDetail.aspx?code=ODg=\&amp;catCode $=\mathrm{OQ}==$.

[2] F. Medda and G. Carbonaro, "Growth of container seaborne traffic in the mediterranean basin: Outlook and policy implications for port development," Transport Reviews, vol. 27, no. 5, pp. 573-587, 2007.

[3] A. Jugovic, S. Hess, and T. P. Jugović, "Traffic demand forecasting for port services," Promet - Traffic - Traffico, vol. 23, no. 1, pp. 59-69, 2011.

[4] A. M. Goulielmos and E. Kaselimi, "A non-linear forecasting of container traffic: the case-study of the Port of Piraeus, 19732008," International Journal of Shipping and Transport Logistics, vol. 3, no. 1, pp. 72-99, 2011.

[5] J. A. M. Lopez, J. J. Ruiz-Aguilar, I. Turias, M. Cerbán, and M. J. Jiménez-Come, "A comparison of forecasting methods for RoRo traffic: A case study in the strait of gibraltar," Advances in Intelligent Systems and Computing, vol. 286, pp. 345-353, 2014.

[6] Royal Haskoning DHV, Container Traffic Forecast Study - port Metro Vancouver, 2014.

[7] S. Hong, V. K. S. Tay, M. Li, S. H. Ng, and K. A. Cher, "Future development of container terminal at Tuas Mega port," Future development of container terminal at Tuas Mega port, 2017.

[8] Google Earth, V 7.1.8.3036 (December 14,2015). South coast of Iran. lat $27.787480 \circ$, lon $58.783370 \circ$, Eye alt $1968.06 \mathrm{~km}$. Landsat/Copernicus.SIO, NOAA, U.S, Navy, NGA, GEBCO, 2017, http://earth.google.com.

[9] Sazeh Pardazi Iran (SPI) Consulting Engineers, Forecasting ports' demand and supply, 2016.

[10] Sazeh Pardazi Iran (SPI) Consulting Engineers, Forecasting maritime transport industry in Iran, 2016.

[11] J. Poncela, Traffic forecasting and planning of port infrastructure, CETMO, 2003.

[12] A. Hajbi, "Traffic Forecasting in Moroccan ports," Supply Chain Forum: An International Journal, vol. 12, no. 4, pp. 26-35, 2011.

[13] F. Tsai and L. J. Huang, "Using artificial neural networks to predict container flows between the major ports of Asia," International Journal of Production Research, vol. 55, no. 17, pp. 5001-5010, 2016.

[14] OCDI, "The Overseas Coastal Area Development Institute of Japan," in Technical Standards for Port And Harbour Facilities in Japan, 2009.

[15] C. A. Thoresen, "Port Designers Handbook," Third edition, 2014.

[16] G. P. Tsinker, Port Engineering-Planning, Construction, Maintenance and Security, 2004.

[17] DNV, Shipping 2020 report, 2012.

[18] SEA Europe, Ships \& Maritime Equipment Association, Market Forecast Report, 2014.

[19] UNCTAD, United Nations Conference on trade and Development, Review of Maritime Transport, 2014.

[20] “Container Ship Types," http://www.globalsecurity.org/military/ systems/ship/container-types.htm.

[21] PIANC, "Master plans for the development of existing ports", Report 158, 2014.

[22] J. Hoffmann, "Corridors of the Sea: An investigation into liner shipping connectivity," in Les corridors Transp, Sous La Dir. Yann Alix, Ed., pp. 263-276, 2012.

[23] “UNCTADSTAT," http://unctadstat.unctad.org/wds/TableViewer/tableView.aspx?ReportId=92.

[24] J. Hoffmann, Liner Shipping Connectivity, UNCTAD, 2007. 


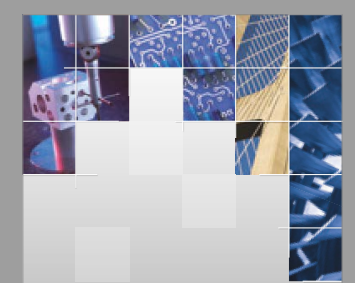

\section{Enfincering}
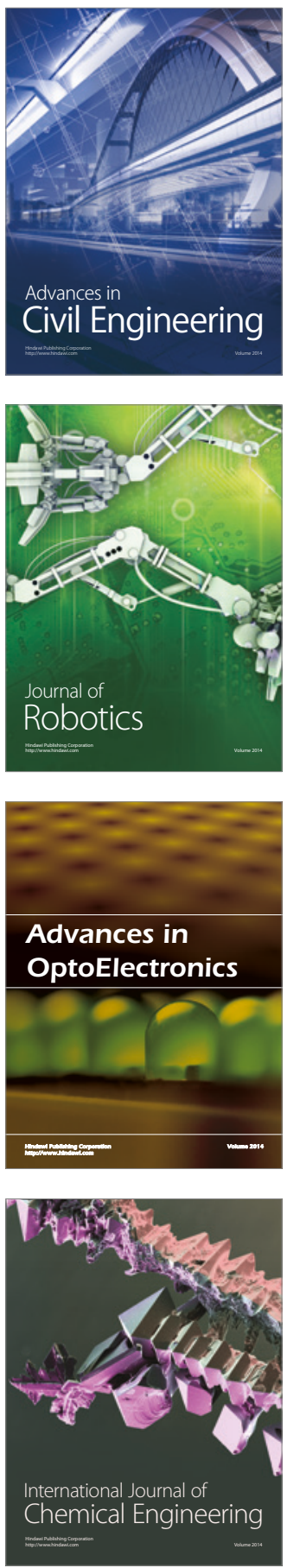

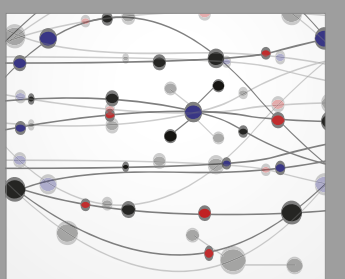

The Scientific World Journal

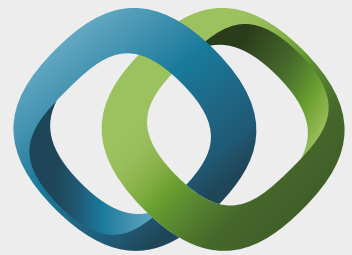

\section{Hindawi}

Submit your manuscripts at

https://www.hindawi.com
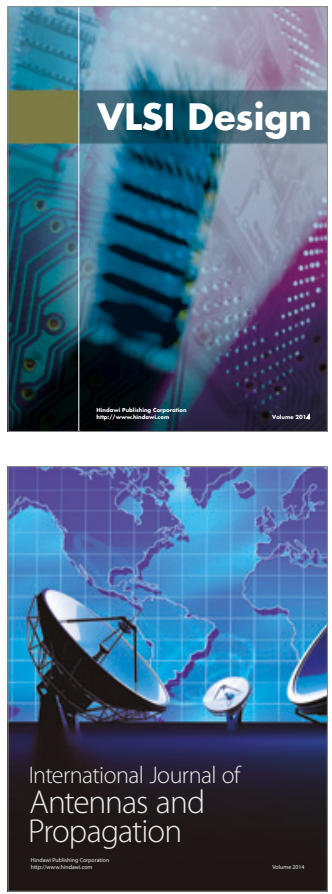

\section{Rotating}

Machinery
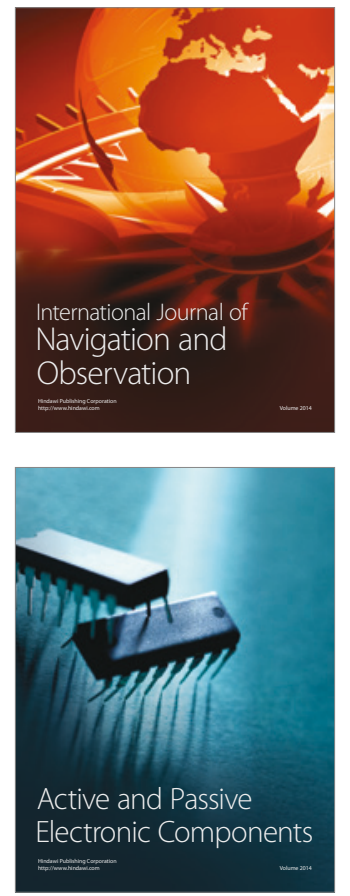
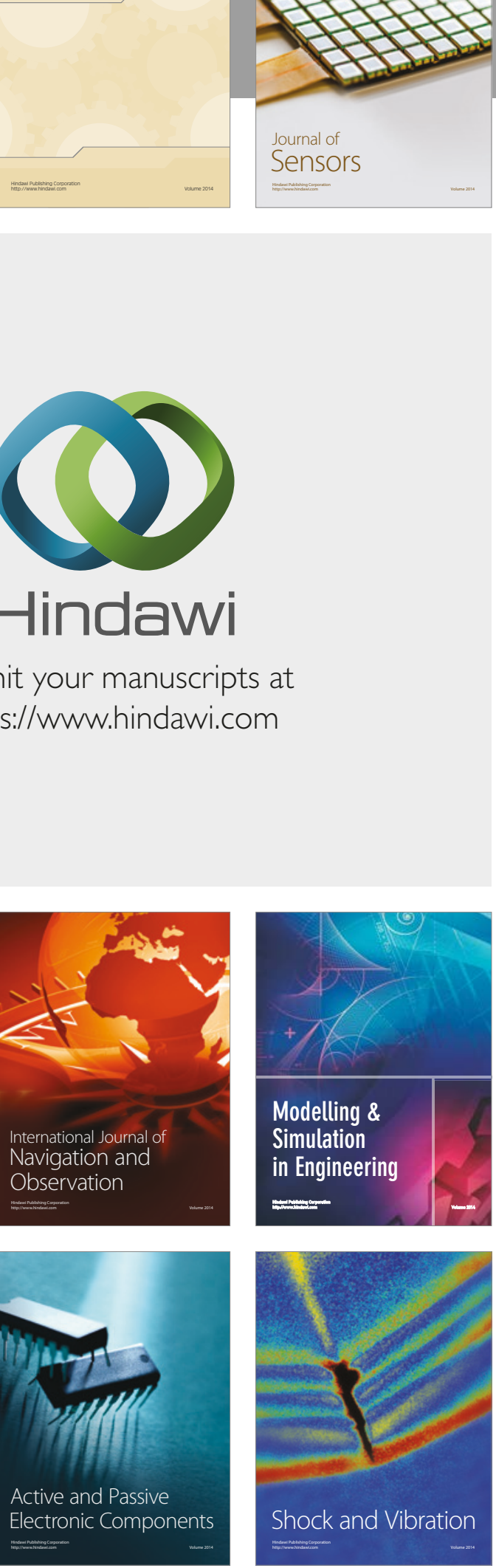
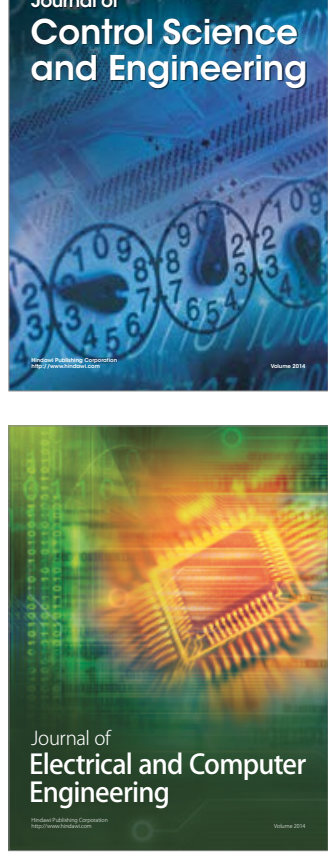

Distributed

Journal of

Control Science

and Engineering
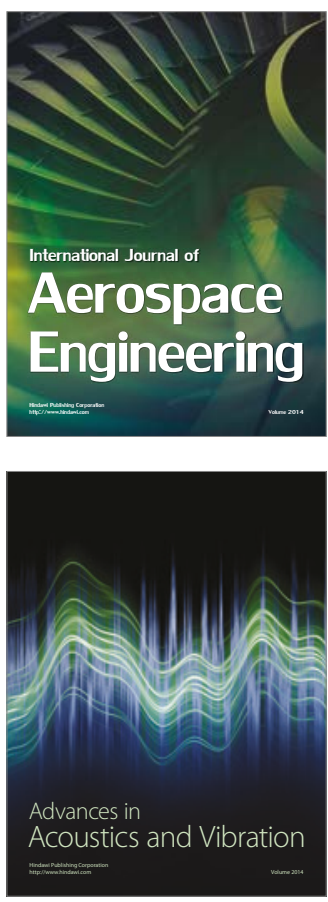

Sensor Networks 